\title{
Developments in Synthesis, Characterization and Applications of Composite lon-exchange Materials: A Review
}

\author{
SANDEEP KAUSHAL ${ }^{1}$, SUSHEEL KUMAR MITTAL ${ }^{2}$ and PRITPAL SINGH ${ }^{1 *}$ \\ 'Department of Chemistry, Sri Guru Granth Sahib World University, Fatehgarh Sahib, Punjab, India. \\ ${ }^{2}$ School of Chemistry and Biochemistry, Thapar University, Patiala, Punjab, India. \\ ${ }^{*}$ Corresponding author E-mail: dhillonps2003@gmail.com \\ http://dx.doi.org/10.13005/ojc/330417
}

(Received: May 30, 2017; Accepted: June 29, 2017)

\begin{abstract}
In this article, a review of hybrid inorganic-organic composite ion exchangers employed as ion sensors, photocatalysts, anti-microbial agents and in water remediation has been carried out. A detailed study of the synthetic procedures, characterization of various composite ion exchangers by different analytical techniques, ion exchange characteristics and their applications has been provided. The applications of the composite ion exchangers in the separation of metal ions, as ion selective electrodes, as photocatalysts in dye degradation and as antimicrobial agents have been reviewed extensively.
\end{abstract}

Keywords: UV resistance, flame retardancy, biodegradation, ionic conductivity.

\section{INTRODUCTION}

Inorganic ion exchangers possess several characteristic features which have led to their numerous applications in diverse fields. The most important property of inorganic ion exchangers is their stability at elevated temperatures and resistance to high radiation fields. Due to their rigid structure, the inorganic ion exchangers possess specific and unusual selectivity, and they do not undergo appreciable dimensional change during the ion exchange process ${ }^{1}$. Initially, the hydrous oxides were studied extensively since they sorbed or co-precipitated many ions. However, the focus was shifted to still superior inorganic ion exchangers synthesized by combining hydrous oxides with anions such as phosphates, antimonates, vanadates and molybdates ${ }^{2-5}$. Inorganic compounds with significant ion exchange capacity have been categorized into 14 classes by Clearfield 6 in his review article. Many more types have been classified by Vesely and Pekarek ${ }^{7}$.

Among the various classes of inorganic ion exchangers listed by different researchers, the synthetic tetravalent metal acid (TMA) salt ion exchangers are of great interest owing to their high thermal and radiation stability, and selectivity towards 
a range of metal ions. The general formula of these materials is $\mathrm{M}^{\mathrm{Iv}}\left(\mathrm{HXO}_{4}\right)_{2} \cdot \mathrm{nH}_{2} \mathrm{O}$, where $\mathrm{M}^{\mathrm{Iv}}=\mathrm{Zr}, \mathrm{Sn}, \mathrm{Ce}$, Ti etc., and $X=M o, P, A s, S b, W$ etc. The presence of structural hydroxyl protons in these materials is responsible for their ion-exchange behaviour ${ }^{8}$. The heteropoly acid salts have a variety of applications in different fields depending on the characteristic properties of the ion exchange material (Table 1).

\section{Composite ion exchangers}

Recently, new kind of advanced composite materials have been synthesized to overcome the limitations of inorganic and organic ion exchange materials. The improved ion exchange properties and mechanical stability of the inorganic-organic composite ion exchangers have generated huge interest in these materials. Earlier organic monomers were incorporated in inorganic matrix to prepare composite ion exchangers. But recently sol-gel method has been extensively employed for the synthesis of organic-inorganic composite ion exchange materials. The composite materials prepared by this method have been used for a variety of applications in diverse fields of chemistry, engineering, biochemistry and environmental science. Moreover, the composite material has absolutely different properties than that of its parent counterparts. The composite materials have potential applications in wide spread areas such as potentiometric sensors, chemical sensors, chromatography, fabrication of ion selective membranes, electro-deionization, membrane electrolysis, electrodialysis, adsorption, thermodynamics, environment and heterogeneous catalysis, due to their in-built multifunctional nature.

\section{Nanocomposite ion exchangers}

The nanocomposites which possess the best properties of each of the components or novel properties, consist of a wide range of materials with nanometer particle size. The properties of nanocomposite materials depend not only on the properties of individual components but also on the morphology and interfacial characteristics. All types and classes of nanocomposite materials possess improved properties as compared to those of their constituents. The nanocomposites not only exhibit drastic improvement in electrical conductivity, UV resistance, flame retardancy, biodegradation, ionic conductivity, and thermal conductivity as compared to that of the original material, but also have better mechanical properties like strength, modulus, and dimensional stability. Other properties that might be substantially improved include reduced permeability to gases, water and hydrocarbons, thermal stability and chemical resistance, surface appearance and optical activity. Therefore, nanocomposites find promising new applications in diverse fields such as mechanical reinforced light weight components, non-linear optics, battery cathodes, solid state ionics, sensors and many others. The researchers are making efforts to develop more efficient and multifunctional nanocomposites ${ }^{30-32}$.

The nanocomposite ion exchangers are preferred over inorganic and organic ion exchangers as they overcome the drawbacks of both types of ion exchangers. They have been prepared by the combination of organic polymer i.e. polystyrene, polyaniline, polyacrylonitrile, poly o-toluidine etc. and inorganic part while retaining the better properties of both the counterparts. The nanocomposite ion exchangers have better mechanical, chemical, thermal and radiation stability, in addition to enhanced reproducibility ${ }^{33-36}$. These organic polymer based hybrid ion exchange materials exhibit improvements in ion exchange properties and selectivity for heavy toxic metals. These materials are granulometric in nature which makes them suitable for column operations also. These multifunctional nanocomposite materials provide extensive range of fascinating properties viz. catalytic activity ${ }^{37}$, optical activity ${ }^{38-39}$ and environmental stability ${ }^{40-42}$. The improvement in performance of nanocomposite materials is attributed to the increased surface area and conductivity ${ }^{43}$. The synthesis, characterization, ion exchange properties and applications of $\mathrm{Zr}$ (IV), Sn (IV) and Th (IV) based nanocomposite ion exchangers have been discussed in the subsequent paragraphs.

Nanocomposite organic-inorganic ion exchange materials have been synthesized recently by many scientists. Organic-inorganic ion exchange material, acrylamide stannic silicomolybdate ${ }^{44}$ selective for $\mathrm{Cu}(\mathrm{II})$ and $\mathrm{Pb}$ (II) ions, an organic-inorganic hybrid ion exchange material, acetonitrile stannic (IV) selenite ${ }^{45}$ having granulometric properties, good ion exchange capacity and selectivity for Th(IV) ions in the mixture of $\mathrm{Ca}(\mathrm{II}), \mathrm{Mg}(\mathrm{II}), \mathrm{Sr}(\mathrm{II}), \mathrm{Ni}(\mathrm{II})$ and $\mathrm{Th}(\mathrm{II})$ ions, a $\mathrm{Cd}(\mathrm{II})$ ion selective polyaniline-cerium (IV) 
Table 1: Inorganic ion exchange materials: Ion exchange capacity, selectivity and applications

\begin{tabular}{|c|c|c|c|c|c|}
\hline $\begin{array}{l}\text { S. } \\
\text { No. }\end{array}$ & Material & $\begin{array}{l}\text { lon Exchange } \\
\text { Capacity }(\mathrm{meq} / \mathrm{g})\end{array}$ & Selectivity & Applications & Reference \\
\hline 1 & $\begin{array}{l}\text { Aluminium } \\
\text { (III)tungstate }\end{array}$ & 1.17 & - & - & 9 \\
\hline 2 & $\begin{array}{l}\text { Cerium(IV)iodot } \\
\text { ungstate }\end{array}$ & 2.86 & - & $\begin{array}{l}\text { Separation of the } \\
{ }^{90} \mathrm{Sr}-{ }^{90} \mathrm{Y} \text { pair }\end{array}$ & 10 \\
\hline 3 & $\begin{array}{l}\text { Chromium(III) } \\
\text { arsenosilicate }\end{array}$ & 0.74 & - & $\begin{array}{l}\text { Adsorption of } \mathrm{Mg}(\mathrm{II}) \text {, } \\
\mathrm{Ca}(\mathrm{II}), \mathrm{Ba}(\mathrm{II}), \mathrm{Sr}(\mathrm{II}), \\
\mathrm{Cu}(\mathrm{II}) \text { and } \mathrm{Al}(\mathrm{III}) \text { in } \\
\text { nicotine and } \mathrm{Ca}(\mathrm{II}), \\
\mathrm{Ba}(\mathrm{II}), \mathrm{Sr}(\mathrm{II}), \mathrm{Fe}(\mathrm{II}), \\
\mathrm{Mn}(\mathrm{II}), \mathrm{Zn}(\mathrm{II}) \text { and } \mathrm{Ni}(\mathrm{II}) \\
\text { ions in pyridine. }\end{array}$ & 11 \\
\hline 4 & $\begin{array}{l}\text { Titanium(IV) } \\
\text { tungstophosphate }\end{array}$ & 0.80 & Eu(III) Sensor & - & 12 \\
\hline 5 & $\begin{array}{l}\text { Zirconium(IV) } \\
\text { molybdotungsto- } \\
\text { vanadosilicate }\end{array}$ & 0.86 & - & Sorption of radionuclides & 13 \\
\hline 6 & $\begin{array}{l}\text { Thorium(IV) } \\
\text { antimonate }\end{array}$ & - & - & $\begin{array}{l}\text { Sorption of } \mathrm{Mg}(\mathrm{II}) \text { and } \\
\mathrm{Zn}(\mathrm{II}) \text { from } \mathrm{Cd}(\mathrm{II})\end{array}$ & 14 \\
\hline 7 & $\begin{array}{l}\text { Titanium(IV) } \\
\text { molybdosilicate }\end{array}$ & 0.74 & - & $\begin{array}{l}\text { Separation of } \mathrm{Fe}(\mathrm{III}) \text { and } \\
\mathrm{Zn}(\mathrm{II}) \text { from } \\
\text { pharmaceutical samples }\end{array}$ & 15 \\
\hline 8 & $\begin{array}{l}\text { Zirconium (IV) } \\
\text { tungstoiodophosp } \\
\text { hate }\end{array}$ & 2.20 & $\mathrm{~Pb}(\mathrm{II})$ & $\begin{array}{l}\text { Separation of binary } \\
\text { solutions }\end{array}$ & 16 \\
\hline 9 & $\begin{array}{l}\text { Stannic } \\
\text { (IV)phosphotung } \\
\text { state }\end{array}$ & - & $\begin{array}{l}\mathrm{Pb}(\mathrm{II}) \\
\mathrm{Ba}(\mathrm{II}) \text { and } \\
\mathrm{Ca}(\mathrm{II})\end{array}$ & - & 17 \\
\hline 10 & $\begin{array}{l}\text { Cerium(IV) phospho } \\
\text { tungstate }\end{array}$ & 1.02 & $\mathrm{Ag}(\mathrm{I})$ & $\begin{array}{l}\text { Chromatographic } \\
\text { separation of } \mathrm{Na}(\mathrm{I}) \text {, } \\
\mathrm{Co}(\mathrm{II}) \text { and } \mathrm{Eu}(\mathrm{III})\end{array}$ & 18 \\
\hline 11 & $\begin{array}{l}\text { Zirconium(IV) } \\
\text { tungstate }\end{array}$ & 1.21 & $\mathrm{Cs}(\mathrm{I})$ & - & 19 \\
\hline 12 & $\begin{array}{l}\text { Zirconium(IV) } \\
\text { silicate }\end{array}$ & 0.91 & - & $\begin{array}{l}\text { Chromatographic } \\
\text { separation of } \mathrm{Na}(\mathrm{I}) \text {, } \\
\mathrm{Co}(\mathrm{I}) \text { and } \mathrm{Eu}(\mathrm{III})\end{array}$ & 20 \\
\hline 13 & $\begin{array}{l}\text { Tin(IV) } \\
\text { boratophosphate }\end{array}$ & 0.80 & $\mathrm{Sm}(\mathrm{III})$ & - & 21 \\
\hline 14 & $\begin{array}{l}\text { Tin(IV) antimono } \\
\text { arsenate }\end{array}$ & 1.00 & $\begin{array}{l}\mathrm{Dy}(\mathrm{III}), \\
\mathrm{Er}(\mathrm{III}), \mathrm{Gd} \\
(\mathrm{III}), \\
\mathrm{Fe}(\mathrm{III}), \\
\mathrm{Pb}(\mathrm{II})\end{array}$ & - & 22 \\
\hline
\end{tabular}




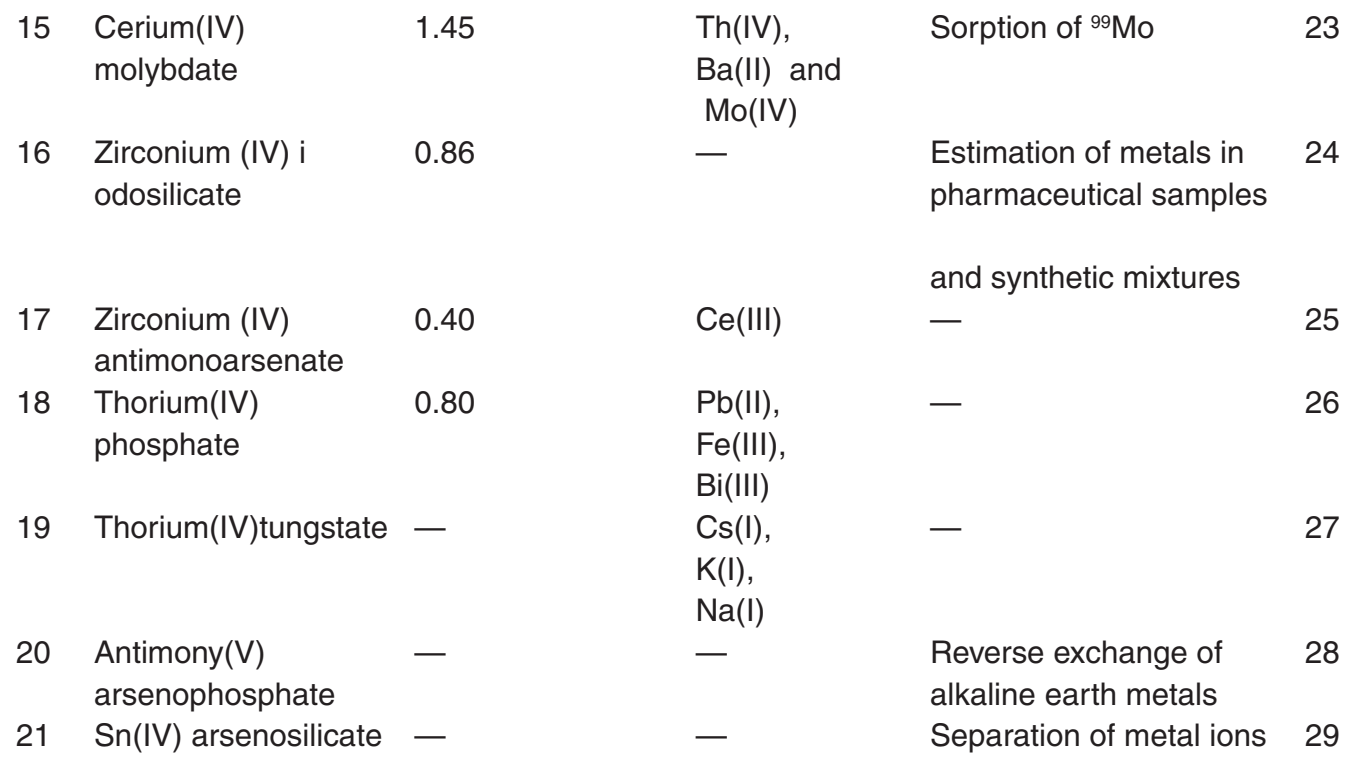

molybdate organic-inorganic hybrid ion exchange ${ }^{46}$ and polypyrrole-based zirconium titanium phosphate nanocomposite ${ }^{47}$ having $20-27 \mathrm{~nm}$ particle size were synthesized by various researchers by sol-gel method.

The sol-gel method was employed for the synthesis of cellulose acetate-tin (IV) molybdate nanocomposite (CA-SnMo) ion exchanger ${ }^{48}$. Binary separations of four metal ions were achieved on the column of this material with recovery of more than $94 \%$ of $\mathrm{Pb}(\mathrm{II})$ and $93 \%$ of $\mathrm{Cd}(\mathrm{II})$ ions in each separation. Polyaniline-tin (IV) tungstophosphate based hybrid cation exchange material ${ }^{49}$ synthesized by sol-gel method was employed for the removal of $\mathrm{Pb}$ (II) ions from industrial waste water. Polypyrrole-zirconium (IV) selenoiodate (PPy/ZrSel) nanocomposite ${ }^{50}$ was synthesized by chemical oxidative polymerization of polypyrrole (PPy) in the presence of zirconium(IV) selenoiodate (ZrSel) by sol-gel method, and polythiophene-tin (IV) phosphate (PTh-SnP) ${ }^{51}$, a polymeric hybrid nanocomposite, by incorporating polythiophene (PTh) in tin phosphate (SnP).

Polyaniline-tin(IV) phosphate ${ }^{52}$ was prepared via sol-gel mixing of organic polymer polyaniline into the matrices of the inorganic precipitate of $\mathrm{Sn}(\mathrm{IV})$ phosphate. The selectivity coefficients determined by the mixed solution method revealed that this material was selective for $\mathrm{Hg}$ (II) in the presence of other interfering cations and hence, $\mathrm{Hg}$ (II) ion selective membrane electrode was prepared using this composite cation-exchanger as the electroactive material. The cation exchanger composite, zirconium(IV) iodosulphosalicylate ${ }^{53}$ was synthesized and characterized by XRD and SEM analysis. The material was employed for the fabrication of $\mathrm{Pb}$ (II) ion selective electrode with a detection limit of $4.78 \mu \mathrm{M}$ and life span of 90 days. The fabricated electrode showed satisfactory performance over a pH range of 4.0-6.5 with a fast response time of $15 \mathrm{~s}$, and was employed for the estimation of $\mathrm{Pb}$ (II) ions in water samples of different origins, ad as an indicator electrode in potentiometric titration and $\mathrm{Pb}(\mathrm{II})$ ions with EDTA.

Polyacrylamide thorium(IV) phosphate ${ }^{54}$ and polycinnamamide thorium(IV) phosphate ${ }^{30}$ were synthesized by co-precipitation method. These materials were characterized by SEM, XRD, FTIR and TGA-DSC techniques. The removal efficiency of polyacrylamide thorium(IV) phosphate and polycinnamamide thorium(IV) phosphate ion exchangers for lead was $52.9 \%$ and $81.2 \%$, respectively, under optimum conditions. The adsorption process on these ion exchangers followed first order kinetics. Adsorption data were fitted to linearly transformed Langmuir isotherm with $R^{2}$ (correlation coefficient) $>0.99$. The equilibrium data were also tested with Dubinin-Radushkevich isotherm to understand the adsorption type. The synthesized poly-o-anisidine tin(IV) tungstate ${ }^{55}$ 
was characterized by various analytical techniques such as XRD, FTIR, SEM, TEM and simultaneous TGA/DTA studies. This composite was employed to fabricate a novel heterogeneous ion-sensitive membrane electrode for the estimation of $\mathrm{Hg}(\mathrm{II})$ ions in solutions. The membrane electrode was mechanically stable with a quick response time, and can be operated over a wide $\mathrm{pH}$ range. The adsorption behavior of zinc (II) dimethyl dithiocarbamate (Ziram) on the surface of nanocomposite cation exchanger poly-o-toluidine zirconium(IV) phosphate ${ }^{56}$ was studied. A Ziram- sensitive membrane electrode was fabricated with poly-o-toluidine $\mathrm{Zr}$ (IV) phosphate as an electroactive material. The sensitivity of the composite cation-exchange material for Ziram was monitored by potentiometric methods.

Poly-o-toluidine zirconium (IV)iodosulfo salicylate ${ }^{57}$ composite ion exchanger had high affinity for $\mathrm{Cr}$ (III) ions. This composite was used as an electroactive material for the fabrication of $\mathrm{Cr}$ (III) selective membrane electrode. The PVC-based $\mathrm{Cr}$ (III) ion-selective membrane is amorphous and porous in nature as indicated by various physical properties determined by XRD, SEM and AFM analysis. The electrode responded to $\mathrm{Cr}$ (III) ions in a linear concentration range of $3.16 \times 10^{-6}$ to $1 \times 10^{-1} \mathrm{M}$ with a detection limit of $1.584 \mu \mathrm{M}$ and had a life span of 12 weeks. The electrode worked satisfactory over a $\mathrm{pH}$ range of 3.0-7.0, with a fast response time of 10s. This sensor was employed for the estimation of $\mathrm{Cr}$ (III) ions in water samples of different origins, and as an indicator electrode in potentiometric titrations of $\mathrm{Cr}$ (III) ions with EDTA. The kinetics and mechanism for the ion-exchange processes like $\mathrm{Mg}(\mathrm{II})-\mathrm{H}(\mathrm{I})$, $\mathrm{Ca}(\mathrm{II})-\mathrm{H}(\mathrm{I}), \mathrm{Sr}(\mathrm{II})-\mathrm{H}(\mathrm{I}), \mathrm{Ba}(\mathrm{II})-\mathrm{H}(\mathrm{I}), \mathrm{Ni}(\mathrm{II})-\mathrm{H}(\mathrm{I})$, $\mathrm{Cu}(\mathrm{II})-\mathrm{H}(\mathrm{I}), \mathrm{Mn}(\mathrm{II})-\mathrm{H}(\mathrm{I})$ and $\mathrm{Zn}(\mathrm{II})-\mathrm{H}(\mathrm{I})$ was studied on the synthesized polyaniline-zirconium(IV) titanium phosphate ${ }^{58}$ ion exchanger at different temperatures using approximated Nernst-Planck equation. Some physical parameters, i.e. fractional attainment of equilibrium $U(\tau) \cup(\tau)$, self-diffusion coefficients $\left(D_{0}\right)$, energy of activation $\left(E_{a}\right)$ and entropy of activation $\left(\Delta S^{\circ}\right)$ were also estimated. It was observed that the equilibrium is attained faster at higher temperature, probably due to availability of thermally enlarged matrix of polyaniline zirconium titanium phosphate (PANI-ZTP) nanocomposite cation exchange material.
The studies ${ }^{59}$ have revealed that polyaniline-Zr(IV)selenoiodate and polyaniline-Zr(IV) selenomolybdate ion exchangers possess excellent ion exchange capacity of 1.36 and 1.44 meq $\mathrm{g}^{-1}$, respectively for $\mathrm{K}(\mathrm{I})$ ion. The organic polymeric part of the composites provides mechanical and chemical stability whereas the inorganic part supports the ion-exchange behaviour and thermal stability. The mechanism for the synthesis of polyaniline- $\mathrm{Zr}(\mathrm{IV})$ selenoiodate and polyaniline-Zr(IV)selenomolybdate composite ion exchangers was discussed and this may also be applied for the preparation of other composite ion exchangers. Sorption behavior of metal ions on the composites was studied in different solvent systems and it was observed that these cation exchange materials are highly selective for $\mathrm{Pb}$ (II) ions.

Polypyrrole has emerged as one of the highly pursued conducting polymer owing to its high electrical conductivity and good environmental stability. A novel organic-inorganic composite polypyrrole zirconium titanium phosphate ${ }^{60}$ was synthesized and characterized by X-ray, TGA-DTA, AAS, FTIR, SEM and TEM. The ion-exchange capacity, $\mathrm{pH}$ titrations and elution behaviour were investigated to explain the ion-exchange properties of the material. Due to its high selectivity for Th (IV) ions, this material was employed for the fabrication of an ion-selective membrane electrode for the estimation of Th (IV) ions in solution.

Cellulose acetate- zirconium (IV) phosphate $(\mathrm{CA} / \mathrm{ZP})^{61}$ ion exchanger was synthesized by sol-gel technique at $\mathrm{pH}$ 0-1, and characterized by X-ray diffraction (XRD), scanning electron microscopy (SEM), energy dispersive X-ray (EDX) spectroscopy, Fourier Transform infrared spectroscopy (FTIR) and thermal analysis Fourier transform (TGA/ DTA/DSC). Ion exchange capacity, pH titrations, elution behaviour, thermal stability and distribution coefficients were investigated to explore the ion exchange behaviour of CA/ZP nanocomposite. The nanocomposite exhibited an ion-exchange capacity of $1.4 \mathrm{meq} \mathrm{g}^{-1}$ for $\mathrm{Na}(\mathrm{I})$ and was highly selective for $\mathrm{Pb}(\mathrm{II})$ and $\mathrm{Zn}(\mathrm{II})$ ions in the presence of many other metal ions. The photocatalytic activity of the CA/ZP nanocomposite was explored for degradation of Congo red dye from aqueous 
phase, and $90 \%$ of the dye was degraded in 60 min of irradiation. Simultaneous adsorption of dye material and photocatalysis by nanocomposite material has synergetic effect on the amount of dye degradation.

Poly-o-anisidine tin(IV)arsenophosphate ${ }^{62}$ was characterized on the basis of its chemical composition, ion exchange capacity, TGA-DTA, FTIR, X-RAY, SEM and TEM studies. Due to its high selectivity for lead, a heterogeneous ion-selective membrane electrode for the estimation of lead in water was developed by using this composite cation exchanger as electroactive material. The membrane

Table 2: Various organic-inorganic composite ion exchangers and their salient features

\begin{tabular}{|c|c|c|c|c|c|}
\hline S. No. & Material & $\begin{array}{l}\text { Ion Exchange } \\
\text { Capacity } \\
\text { (meq/g) }\end{array}$ & Selectivity & Application(s) & Reference \\
\hline 1 & $\begin{array}{l}\text { Polyaniline-Zr(IV) } \\
\text { molybdophosphate }\end{array}$ & 2.50 & $\mathrm{Ni}(\mathrm{II})$ & $\begin{array}{l}\mathrm{Ni} \text { (II) selective } \\
\text { electrode }\end{array}$ & 82 \\
\hline 2 & $\begin{array}{l}\text { Polystyrene } \mathrm{Zr}(\mathrm{IV}) \\
\text { tungstophosphate }\end{array}$ & -- & $\mathrm{Hg}(\mathrm{II})$ & -- & 83 \\
\hline 3 & $\begin{array}{l}\text { Pyridinium- } \\
\text { tungstoarsenate }\end{array}$ & -- & $\begin{array}{l}\mathrm{Cs}(\mathrm{I}) \& \\
\mathrm{Ag}(\mathrm{I})\end{array}$ & -- & 84 \\
\hline 4 & $\begin{array}{l}\text { Polyaniline-tin(IV) } \\
\text { tungstophosphate }\end{array}$ & 1.1 & -- & $\begin{array}{l}\text { Removal of } \mathrm{Pb} \text { (II) } \\
\text { from wastewater }\end{array}$ & 85 \\
\hline 5 & $\begin{array}{l}\text { Polyaniline- } \\
\text { zirconium titanium } \\
\text { phosphate }\end{array}$ & -- & -- & $\begin{array}{l}\mathrm{Hg} \text { (II) selective } \\
\text { electrode }\end{array}$ & 86 \\
\hline 6 & $\begin{array}{l}\text { Polyaniline Ce (IV) } \\
\text { molybdate }\end{array}$ & -- & -- & $\begin{array}{l}\text { Cd (II) selective } \\
\text { electrode }\end{array}$ & 87 \\
\hline 7 & $\begin{array}{l}\text { poly-o-toluidine- } \\
\text { thorium(IV) } \\
\text { molybdophosphate }\end{array}$ & 1.22 & $\begin{array}{l}\mathrm{Pb}(\mathrm{II}) \& \\
\mathrm{Hg}(\mathrm{II})\end{array}$ & $\begin{array}{l}\mathrm{Hg}(\mathrm{II}) \text { selective } \\
\text { electrode }\end{array}$ & 88 \\
\hline 8 & $\begin{array}{l}\text { poly-o-toluidine } \\
\mathrm{Zr}(\mathrm{IV}) \text { tungstate }\end{array}$ & -- & $\mathrm{Hg}(\mathrm{II})$ & $\begin{array}{l}\text { Binary separations of } \\
\text { heavy metal ions }\end{array}$ & 89 \\
\hline 9 & $\begin{array}{l}\text { poly-o-toluidine } \\
\text { stannic molybdate }\end{array}$ & -- & $\begin{array}{l}\mathrm{Pb}(\mathrm{II}) \& \\
\mathrm{Hg}(\mathrm{II})\end{array}$ & $\begin{array}{l}\text { Binary separations of } \\
\text { heavy metal ions }\end{array}$ & 90 \\
\hline 10 & $\begin{array}{l}\text { poly-o- } \\
\text { methoxyaniline } \\
\mathrm{Zr}(1 \mathrm{~V}) \text { molybdate }\end{array}$ & -- & -- & $\begin{array}{l}\text { Cd (II) selective } \\
\text { electrode }\end{array}$ & 91 \\
\hline 11 & $\begin{array}{l}\text { Poly-o-anisidine tin } \\
\text { (IV) tungstate }\end{array}$ & 2.25 & $\mathrm{Hg}(\mathrm{II})$ & $\begin{array}{l}\text { Binary separations of } \\
\text { heavy metal ions }\end{array}$ & 92 \\
\hline 12 & $\begin{array}{l}\text { Polypyrrole } \\
\text { thorium(IV) } \\
\text { phosphate }\end{array}$ & -- & $\mathrm{Pb}(\mathrm{II})$ & $\begin{array}{l}\mathrm{Pb}(\mathrm{II}) \text { selective } \\
\text { electrode }\end{array}$ & 93 \\
\hline 13 & $\begin{array}{l}\text { Polyaniline tin(IV) } \\
\text { molybdophosphate }\end{array}$ & -- & $\begin{array}{l}\mathrm{Pb}(\mathrm{II}) \text { and } \\
\mathrm{Cu}(\mathrm{II})\end{array}$ & $\begin{array}{l}\text { Binary separations of } \\
\text { heavy metal ions }\end{array}$ & 94 \\
\hline 14 & $\begin{array}{l}\text { Poly-o-toluidine- } \\
\text { zirconium } \\
\text { phosphoborate }\end{array}$ & -- & $\mathrm{Hg}(\mathrm{II})$ & $\begin{array}{l}\mathrm{Hg} \text { (II) selective } \\
\text { electrode }\end{array}$ & 95 \\
\hline 15 & $\begin{array}{l}\text { Polyaniline- } \\
\text { zirconium } \\
\text { phosphoborate }\end{array}$ & 0.67 & -- & Dye adsorption & 96 \\
\hline
\end{tabular}


electrode was mechanically stable, had a quick response time, and can be operated over a wide $\mathrm{pH}$ range. The practical utility of this membrane electrode was established by employing it as an indicator electrode in the potentiometric titrations of $\mathrm{Pb}$ (II). Poly acrylamide zirconium (IV) iodate ${ }^{63}$ with an ion exchange capacity of 3.27 meq g $^{-1}$ for $\mathrm{Pb}$ (II) was synthesized by employing sol-gel technique. The synthesis conditions such as reactant concentrations and temperature were varied to optimize the ion exchange properties of the hybrid organic-inorganic ion exchange material which was characterized on the basis of chemical composition, FTIR, XRD, TGADTA, SEM and EDX studies. The sorption studies indicated that the hybrid cation exchanger has a high selectivity for $\mathrm{Pb}$ (II) in comparison to other metal ions. Some important binary separations like $\mathrm{Hg}$ (II)$\mathrm{Pb}$ (II), $\mathrm{Cu}(\mathrm{II})-\mathrm{Pb}(\mathrm{II}), \mathrm{Ni}(\mathrm{II})-\mathrm{Pb}(\mathrm{II}), \mathrm{Fe}(\mathrm{III})-\mathrm{Pb}$ (II) and $\mathrm{Cd}(\mathrm{II})-\mathrm{Pb}(\mathrm{II})$ were performed on this exchanger. In addition, the selective separation of $\mathrm{Pb}$ (II) was also achieved from a synthetic mixture containing a large number of metal ions with a recovery of <"98.5\%. The material was successfully used for the selective removal of $\mathrm{Pb}$ (II) from waste water samples.

Diverse techniques such as agar diffusion method and colony forming unit method have been employed for investigating the antibacterial activities of nanocomposites against pathogenic bacteria. The major advances in antibacterial drug development in the middle of $20^{\text {th }}$ century helped to control the infection in humans ${ }^{64}$. In the last few years, new metal complexes for antibacterial activity have been synthesized, and investigated for their antibacterial, antifungal and anti cancerous nature. Metal ion based nanomaterials exhibit broad spectrum biocidal activity towards different fungi, bacteria and viruses. Pectin-thorium (IV) tungstomolybdate (Pc/ TWM) nanocomposite ${ }^{65}$ was synthesized by mixing biopolymer pectin with its inorganic counterpart thorium (IV) tungstomolybdate by sol-gel method. The nanocomposite exhibited significant antibacterial activity towards E. coli bacteria.

A novel cellulose acetate-tin(IV) molybdate (CA/TM) nanocomposite exchanger66 was synthesized and characterized by Fourier transform infrared spectroscopy (FTIR), scanning electron microscopy (SEM), transmission electron microscopy (TEM), X-ray diffraction (XRD), and thermal analysis techniques. The nanocomposite was found to be selective for $\mathrm{Pb}$ (II) and $\mathrm{Cd}(\mathrm{II})$ ions on the basis of distribution coefficient $\left(K_{d}\right)$ values. The antibacterial activity of CA/TM nanocomposite was explored against Escherichia coli. A new biopolymer based nanocomposite, pectin zirconium(IV) selenotungstophosphate $(\mathrm{Pc} / Z S W P)^{67}$ was synthesized by sol-gel method. This nanocomposite was effective in inhibiting the growth of $\mathrm{S}$. aureus bacteria in 22 hours. Cellulose acetate-tin (IV) phosphate (CA/TP) nanocomposite was prepared by Rathore ${ }^{68}$ et al. The ion exchanger was characterized by Fourier transform infrared spectroscopy (FTIR), transmission electron microscopy (TEM), scanning electron microscopy (SEM), energy dispersive X-ray spectroscopy (EDX), X-ray diffraction (XRD), and thermogravimetric analysis (TGA/DTA/DSC). The nanocomposite was observed to be more selective for $\mathrm{Cd}$ (II) and $\mathrm{Mg}$ (II) on the basis of distribution coefficient studies. The nanocomposite was explored for antibacterial activity against $\mathrm{E}$. coli bacteria.

Polyanilinezirconium(IV) tungstoiodo phosphate(PANI-ZWIP) nanocomposite ${ }^{69}$ ion exchanger was synthesized by sol-gel method. The antimicrobial activities of PANI and PANIZWIP nanocomposite ion exchanger were studied against E. coli and Proteus vulgaris bacteria. The nanocomposite ion exchanger showed higher antimicrobial activity against both E. coli and Proteus vulgaris. Recently, Pathania and co-workers ${ }^{70}$ synthesized polyaniline-zirconium silicophosphate (PANI-ZrSiP) nanocomposite cation exchanger by sol gel method employing polyaniline (PANI) gel and inorganic precipitates of zirconium silicophosphate ( $\mathrm{ZrSiP})$ at $\mathrm{pH} \approx 1$ that was successfully used as an antibacterial agent against Escherichia coli (E.Coli.), and as a photocatalyst for removal of methylene blue dye from water.

Diverse techniques such as coagulation, chemical oxidation, microbial degradation, adsorption and photocatalysis are usually employed for the removal of organic pollutants including dyes from aqueous systems $\mathrm{s}^{71-72}$ but photocatalysis is the most preferred method due to fast degradation of dye, simplicity and generation of non-toxic materials ${ }^{73}$. Various types of nanoparticles such as $\mathrm{CdS}, \mathrm{Fe}_{2} \mathrm{O}_{3}$, $\mathrm{ZnO}$ and $\mathrm{TiO}_{2}$ etc. have been investigated as efficient photocatalysts for the degradation of organic 
pollutants ${ }^{74}$. However, the composite ion exchangers with nano scale dimensions have attracted a great concern due to their varied applications in different fields. The composite ion exchangers exhibit high efficiency in heterogeneous photocatalytic processes. Styrene-tin (IV) phosphate (ST/TP) nanocomposite ion exchanger ${ }^{75}$ synthesized by sol gel method was used as an efficient photocatalyst for the degradation of methylene blue dye from aqueous system in the presence of solar light. Polyaniline zirconium(IV) silicophosphate (PANI-ZSP) nanocomposite was synthesized ${ }^{76}$ and used for sorptive removal of methylene blue dye from aqueous system. The maximum adsorption capacity of methylene blue (MB) on PANI-ZSP was found to be $12 \mathrm{mg} / \mathrm{g}$. The adsorption of MB onto PANI-ZSP nanocomposite followed the second-order kinetics and best fitted the Frendluich isotherm.

A novel nanocomposite cation exchanger polyaniline- tin(IV) iodophosphate (PANI-SnIP) ${ }^{77}$ was synthesized using sol"gel method and photo degradion of methylene blue (MB) dye under solar irradiation was carried out by this nanocomposite. Patil et $a \Gamma^{8}$ developed a novel method for the removal of color from textile dying wastewater by using conducting polyaniline- $\mathrm{NiFe}_{2} \mathrm{O}_{4}$ waste water composite that was synthesised in situ through self polymerisation of monomer aniline. Photocatalytic degradation studies were carried out for water soluble carcinogenic methylene blue (MB) dye and it was observed that photocatalytic degradation by PANI-NiFe ${ }_{2} \mathrm{O}_{4}$ nanocomposite is a more effective and faster mode of removing methylene blue (MB) dye. Polyacrylamide $\mathrm{Zr}(\mathrm{IV})$ vanadophosphate (PAM/ZVP) nanocomposite ${ }^{79}$ synthesized by sol gel method exhibited very good results for the degradation of Congo red dye under sunlight.
The enhanced dye degradation was observed as the nanocomposite behaved as adsorbent and photocatalyst simultaneously. In another study, the synthesized polyaniline-tin (IV) iodophosphate (PANI-SnIP) nanocomposite ion exchanger ${ }^{80}$ with particle size $20-25 \mathrm{~nm}$ was used as a photocatalyst for degradation of methylene blue dye in solar light.

Akhtar and co-workers ${ }^{81}$ reported the synthesis of poly-o-toluidine-thorium(IV) molybdophosphate (POT-ThMoP), a new hybrid cation exchanger by sol-gel method, by the incorporation of inorganic precipitates of thorium (IV) molybdophosphate into the matrices of organic poly-o-toluidine at $\mathrm{pH} \approx 1$. The material was selective for $\mathrm{Hg}(\mathrm{II})$ and $\mathrm{Pb}(\mathrm{II})$ ions in different solvent media and degraded about $74 \%$ of Congo red dye within $8 \mathrm{~h}$ of irradiation with the ion exchanger as a photocatalyst.

\section{CONCLUSION}

The composites ion exchange materials have distinct advantages over their organic and inorganic counterparts due to their exceptional mechanical strength, thermal stability and better ion exchange properties. They are also suitable for column operations due to their granulometric nature. The composite ion exchangers are highly selective for heavy metal ions and are thus employed to remove traces of heavy metal ions from the industrial effluents. These have also been employed as efficient photocatalysts for degradation of organic dyes and other pollutants. A number of ion selective electrodes for the estimation of different types of metal ions have been fabricated using these hybrid materials. It can be concluded that these hybrid ion exchange materials hold a promising future for environmental remediation.

\section{REFERENCES}

1. Abe, M. Ion Exch. \& Solvent Extr. 1995, 12, 4. 381-434.

2. Kraus, K. A.; Phillips, H. O. J. Am. Chem. Soc. 1956, 78, 644-650.

3. Kraus, K. A.; Phillips, H.O.; Carlson, T. A.; Johnson, J. S. $2^{\text {nd }}$ UN Conf. Peaceful Uses At. Energy, Geneva. 1958, 28, 3.
Amphlett, C. B. $2^{\text {nd }}$ UN Conf. Peaceful Uses At. Energy, Geneva, 1958, 28, 17-22.

5. Amphlett, C. B. Inorganic Ion exchangers, Elsevier. 1964, Amsterdam.

6. Clearfield, A. Inorganic Ion Exchange Materials, CRC Press Boca Raton. 1982, FL. 
7. Pekarek, V.; Vesely, V. Talanta. 1972, 19, 12451283.

8. Yates, S. F.; Sylvester, P. Sep. Sci. Technol. 2001, 36(5-6), 867-883.

9. Nabi, S. A.; Naushad, M. Coll. Surf. A: Phys. Eng. Asps. 2007, 393(1), 175-184.

10. Dhara, S.; Sarkar, S.; Basu, S.; Chattopadhyay, P. J. App. Rad. Isot. 2009, 67(4), 530-536.

11. Varshney, K. G.; Khan, A. A.; Siddiqui, M. S. Coll. Surf. 1989, 36(3), 405-416.

12. Siddiqi, Z. M.; Pathania, V. J. Acta. Chromato., 2003, 987 (1-2), 147-153.

13. Zonoz, F. M.; Ahmadi, S. J.; Nosrati, S. A.; Margheh, M. G. J. Haz. Mater. 2009, 169(1-3), 808-812.

14. De, A. K.; Das, S. K. Chromatographia. 1978, 11(6), 350-356.

15. Nabi, S. A.; Shalla, A. H.; Khan, A. M.; Ganie, S. A. Coll. Surf. A: Phys. Eng. Asp. 2007, 302 (1-3), 241-250.

16. Siddiqui, W. A.; Khan, S. A. Bull. Mater. Sci. 2007, 30(1), 43-50.

17. Mittal, S. K.; Sahu, R.N.; Banait, J. S. J. Phys. Sci. 2007, 1,1-7.

18. Raj, P. L. Orient. J. Chem. 2011, 7(3), 12571260.

19. Attallah, M. F.; Borai, E. H.; Harjula, R.; Paajanen, A.; Karesoja, M.; Koivula, R. J. Mater. Sci. Eng. B. 2011, 1, 736-739.

20. El-Gammal, B.; Shady, S. A. Coll. Surf. A: Phys. Eng. Asp. 2006, 290, 38-142.

21. Mittal, S. K.; Sharma, H. K. J. Ion Exchange. 2006, 17, 2-6.

22. Mittal, S. K.; Singh, P. P. React. Funct. 1999, 40(3), 231-240.

23. Nilchi, A.; Maalek, B.; Khanchi, A.; Maragheh, M. G.; Bagheri, A. Rad. Phy. Chem, 2006, 75, 301-308.

24. Nabi, S. A.; Ganai, S. A.; Naushad, M. Desalin. Water Treat. 2010, 16(1-3), 29-38.

25. Mittal, S. K.; Sharma, H. K.; Kumar, S. K. A. React. Funct. Poly. 2006, 66, 1174-1181.

26. De, A. K.; Chowdhury, K. J. Chromatogr.1974, 101, 63-72.

27. Qureshi, M.; Nabi, S. A. J. Chem. Soc. (A), 1971, 139, 1-3927.

28. Varshney, K. G.; Khan, A. A.; Khan, A. R. Bull. Chem. Soc. (Japan). 1988, 61, 3693-3697.

29. Khan, A. A.; Maheshwari, A.; Sharma, U. Indian J. Chem. Technol. 1984, 22, 99-103.

30. Deka, B. K.; Mandal, M.; Maji, T. K.; Ind. Eng. Chem. Res. 2012, 51 (37), 11881-11891.

31. Ruban, Y. J. V.; Ginil, S.; Roy, M. D. V. Appl.
Nanosci. 2014, 4(2), 233-240.

32. Jayaramudu, J.; Agwuncha, S. C.; Ray, S. S.; Sadiku, E. R.; Rajulu, A. V. Adv. Mater. Lett. 2015, 6(2), 114-119.

33. Zhang, H.; Pang, J. H.; Wang, D.; Li, A.; Li, X.; Jiang, Z. J. Membr. Sci. 2005, 264, 56-64.

34. Khan, A. A.; Inamuddin; Alam, M. M. Mater. Res. Bull. 2005, 40, 289-293.

35. Gupta, V.K.; Pathania, D.; Agarwal, S.; Singh, P. J. Hazard. Mater. 2012, 243,179-186.

36. Varshney, K. G.; Tayal, N.; Khan, A. A.; Niwas, R. Colloids Surf. A: Phys. Chem. Eng. Aspect. 2001, 181,123-129.

37. lijma, M.; Kamiya, H. Kona Powder Part. J. 2009, 27, 119-129.

38. Kondawar, S. B.; Agarwal, S. P.; Nimkar, S. H.; Sharma, H. J.; Patil, P. T. Adv. Mater. Lett. 2012, 3, 393-397.

39. Pinnavaia, T. J. Science, 2002, 220,365371.

40. Mojumdar, S. C. Res. J. Chem. Environ. 2005, 9, 23-24.

41. Gupta, V. K.; Pathania, D.; Singh, P.; Rathore, B. S.; Chouhan, P. Carbohydr. Polym. 2013, 95, 434-440.

42. Crinic, G. Bioresour. Technol., 2006, 97, 10611067.

43. Khan, A.; Asiri, A. M.; Rub, M. A.; Azum, N.; Khan, A. A. P.; Khan, S. B.; Rahman, M. Compos. Part B. 2013, 45, 486-496.

44. Kaneko, Y.; Lyi, N.; Matsumoto, T.; Kitampura, K. Electrochim. Acta, 2005, 48(17), 15721578.

45. Nabi, S.A.; Bushra, R.; Al-Othman, Z. A.; Naushad, M. Sep. Sci. Technol. 2011, 46 (5), 847-857.

46. Alam, Z.; Nausad, M.; Nabi, S. A. J. Inorg. Org. Metall. Poly. Mater. 2012, 22(2), 379-385.

47. Khan, A. A.; Paquiza, L. Synth. Met. 2011, 161, 899-905.

48. Nabi, S. A.; Akhtar, A.; Khan, M. D. A.; Khan, M. A. Desalination, 2015, 361, 1-12.

49. Nabi, S. A.; Akhtar, A.; Khan, M. D. A.; Khan, M. A. Desalination, 2014, 340, 73-83.

50. Khan, A. A.; Rao, R. A. K.; Alam, N.; Shaheen, S. Sens. Actuat. B: Chem. 2012, 211, 419427.

51. Khan, A.; Asiri, A, M.; Khan, A. A. P.; Khan, S. B.; Arab. J. Chem. 2014, 1-7.

52. Khan, A. A.; Alam, M. M.; Inamudidin. Sensor and Actuat. B: Chem., 2006, 120, 10-18.

53. Rashid, M.; Khan, F.; Lutfullah. J. Water Process. Eng. 2014, 3, 53-61. 
54. Islam, M.; Patel, R. J. Hazard. Mater. 2009,172, 707-715.

55. Khan, A. A.; Shaheen, S. Composites: part B. 2013, 44, 692-697.

56. Khan, A. A.; Inamuddin; Akhtar, T. Electrochimica Acta, 2008, 53(17), 55405548.

57. Lutfullah; Rashid, M.,; Khan, F.; Wahab, R. Ind. Eng. Chem. Res. 2014, 53,14897-14903.

58. Khan, A. A.; Paquiza, L. Desalination, 2011, 265, 242-247.

59. Mispa, K. C.; Muthulakshmi, R.; Kumar, C. P.; Subaramaniam, P.; Murugesan, R. PolymPlast. Technol., 2017, 56, 55-70.

60. Khan, A. A.; Paquiza, L.; Khan A. J. Mater. Sci. 2010, 45, 3610-3616.

61. Gupta, V.K.; Pathania, D.; Chauhan, P. Carbohyd. Poly. 2013, 95, 434-440.

62. Khan, A. A.; Habiba, U.; Khan, A. Int. J. Anal. Chem., 2009, doi:10.1155/2009/659215.

63. Rehman, N.; Haseen, U.; Rashid, M. Arab. J. Chem. 2013, (Article in Press).

64. Feng, Q. L.; Wu, J.; Chen, G.Q.; Chui, F. Z.; Kim, T. N.; Kim, J. O. J. Biomed. Mater. Res., 2002, 52, 662-668

65. Gupta, V. K.; Agarwala, S.; Pathania, D.; Kothiyal, N.C.; Sharma, G. Carbohyd. Polym.2013, 96, 273-283.

66. Gupta, V. K.; Agarwal, S.; Tyagi, I.; Pathania, D.; Rathore, B. S.; Sharma, G. "Synthesis, lonics, 2014, 21, 221-229.

67. Sharma, G.; Pathania, D.; Naushad, M. Ind. Eng. Chem. Res. 2014, 20, 4482-4490.

68. Rathore, B. S.; Sharma, G.; Pathania, D.; Gupta, V. K. Carbohyd. Poly. 2014, 103, 221227.

69. Mispa, K. J.; Subramaniam, P.; Murugesan, R.; J. Polym. 2013, 124, 1-12.

70. Pathania, D.; Sharma, G.; Kumar, A.; Koyhyal, N. C. J.Alloys and Comp. 2014, 588, 668673.

71. Korbahti, B. K.; Gecgel, K. C.; Ozer, A. Chem. Eng. J. 2011, 173, 677-684.

72. Sampa, C.: Binay, K. D. J. Colloid Interface Sci., 2005, 286, 807-812.

73. Quada, E. El.; Allen, S. J.; Walker, G. Chem. Eng. J. 2008, 135, pp.174-180.

74. Seoudi R.; Shabaka A. A., Kamal, M.; Abdelrazek, E. M.; Eisa, W. Physica E. 2012, 45, 47-55.
75. Rathore, B. S.; Pathania, D. J Alloy Compd.2014, 606, 105-111.

76. Gupta, V. K.; Pathania, D.; Kothiyal, N. C.; Sharma, G. J. Mol. Liq. Journal, 2013, 190, 139-145.

77. Khan, M. D. A.; Akhtar, A.; Nabi, S. A.; Khan. M. A. Ind. Eng. Chem. Res., 2014, 53, 1525315260.

78. Patil, M. R.; Shrivastava, V.S. J. Mater. Environ. Sci. 2015, 6 (1), 11-21.

79. Sharma, G.; Kumar, A.; Naushad, M.; Pathania, D.; Sillanpaa, M. J. Ind. Eng. Chem. 2016, 33, 201-208.

80. Khan, M. D. M.; Akhtar, A.; Navi, S.A.; Khan, M. A. Ind. Eng. Chem. Res. 2014, 53, 1525315260.

81. Akhtar, A.; Dilwar, M.; Khan, A.; Nabi, S.A. Desalination, 2015, 361, 1-12.

82. Khan, A. A.; Shaheen, S. J. Electroanal. Chem. 2014, 714, 38-44.

83. Niwas, R.; Khan, A. A.; Varshney, K. G. Ind. J. Chem., 2014, 37A, 469-472.

84. Malik, W. U., Srivastava, S. K. and Kuamr, S., Talanta, 23(4), pp. 323-325.

85. Nabi, S.A.; Khan, M. A. Desalination, 2014, 340, 73-83.

86. Khan, A. A.; Paquiza, L. Desalination, 2014, 272, 278-285.

87. Alam, Z.; Inamuddin; Nabi, S. A., Desalination, 2010, 250, 515-522.

88. Akhtar, A.; Khan, M. D. A.; Nabi, S. A Desalination, 2015, 361, 1-12.

89. Al-Otham, Z. A.; Nausad, M.; Innamuddin. Chem. Eng. J. 2011, 172, 369-375.

90. Nabi, S.A.; Bushra, R.; Naushad, M.; Khan, A. M. Chem. Eng. J. 2010, 165, 529-536

91. Inamuddin; Ismail, Y. A. Desalination, 2010, 250, 523-529.

92. Khan, A. A.; Shaheen, S. Composites: Part B. 2013, 44, 692-697.

93. Khan, A.A.; Inamuddin; Alam, M.M. React. Funct. Polym. 2005, 63,119-133.

94. Semagne, B.; Diaz, I.; Kebede, T.; Teddesse, A.M. React. Funct. Polym. 2016, 98, 17-23.

95. Kaushal, S.; Badru, R.; Kumar, S.; Mittal, S. K.; Singh, P. RSC Advances, 2016, 6, 31503158.

96. Kaushal, S.; Badru, R.; Kumar, S.; Mittal, S. K.; Sharma, P. K.; Singh, P. RSC Advances. 2016, 6, 111606-111615. 